\title{
Pengaruh motivasi kepemimpinan dan kerja yang ada pada perusahaan (Firm Performance)
}

Nama : haqqan amien maziun

Email : haqqanamien1@gmail.com

Dalam metode bibliometrik untuk menjelaskan literatur yang masih ada dalam prosedur operasi untuk mengembangkan konseptual tentang karakteristik dan fungsi dalam intelijen bisnis. Dalam analisis yang bergerak di bidang penelitian yang di fokuskan untuk memproses atribut umum dari konstruksi teoritis. proses bisnis dapat secara signifikan mengurangi biaya operasi dan meningkatkan profitabilitas perusahaan dalam bisnis. Untuk fungsi dalam intelijen bisnis, proses dinamis yang dimulai dengan pengetahuan kognitif, integrasi informasi, dan pemanfaatan pengetahuan yang ditangkap, dan diakhiri dengan kemampuan mengemudi meningkatkan mekanisme pembelajaran, dan mengubah sumberdaya perusahaan. (Chen \& Lin, 2020)

Dalam hubungan positif antara kemampuan analisis data besar dan kinerja perusahaan telah menyetujui pentingnya pengambilan keputusan berdasarkan bukti. Pada kinerja proses bisnis dan pengambilan keputusan telah ditemukan memiliki efek mediasi pada hubungan positif antara kemampuan manajemen informasi dan kinerja suatu perusahaan dalam meneliti peran mediasi. keselarasan strategi bisnis dalam kinerja perusahaan melalui kemampuan analisis data besar untuk menerapkan pengaturan kesehatan dengan sukses, terdapat lima strategi yaitu: (1) penerapan tata kelola analisis data besar, (2) penciptaan budaya berbagi informasi, (3) pelatihan personel kunci untuk menggunakan analisis data besar, (4) integrasi komputasi awan ke dalam organisasi. Analisis big data, dan (5) pembuatan ide bisnis baru dari analisis Big data. (Yasmin, Tatoglu, Kilic, Zaim, \& Delen, 2020)

Kinerja perusahaan dalam literatur baru-baru ini digunakan dengan konteks kinerja keuangan, kinerja pelanggan, kinerja Proses Bisnis Internal, dan kinerja pembelajaran pertumbuhan. Lalu ada serangkaian publikasi tentang kinerja perusahaan di berbagai geografi dan konteks. Demikian literatur yang telah di terbitkan telah mempelajari dimensi kinerja perusahaan. Penelitian ini untuk tidak hanya mempelajari dimensi fungsional saja, akan tetapi juga menyelidiki kinerja perusahaan wholistic dalam semua aspek. (Gupta \& Gupta, 2020)

Dalam studi yang menggunakan produk development sebagai variabel yang dapat mengukur open innovation (Pratono, 2018). Orientasi kewirausahaan hijau juga memiliki dampak positif pada kinerja perusahaan (Jiang et al., 2018). Terdapat juga pada orientasi kewirausahawan yang terdapat pada perilaku suatu perusahaan yang mengambil sebuah resiko, otonomi, dan inovatif (Covin dan Miller, 2014). Open innovation juda memiliki peran penting dalam proses perkembangan sebuah produk yang sedang berkaitan dengan bagaimana suatu perusahaan yang memiliki competitive advantage dengan open resource yang lebih terpusat kesebuah inovasi yang ada pada perusahaan tersebut. Yaitu inovasi produk merupakan sebuah elemen utama orientasi kewirausahaan, yang dapat mempengaruhi keunggulan sebuah kompetitif berkelanjutan pada suatu jaringan dan kemitraan (Pratono, 2018). Terdapat definisi strategi dalam literatur. Yang pertama berpendapat bahwa strategi merupakan konsistensi 
perilaku organisasi dalam mencapai tujuan mereka (Mintzberg dan Waters, 1985). Strategi merupakan mekanisme bagaimana fokus perusahaan pada upaya untuk mencapai kinerja yang diharapkan (Wiesner dan Millet, 2012). Strategi juga dianggap sebagai mekanisme terhadap suatu perusahaan dalam upaya mencapai kinerja yang baik dengan membuat sebuah konsep orientasi strategis agar perusahaan dapat didasarkan oleh peluang dan sumberdaya (Pratono, 2016).

Chen, Y., \& Lin, Z. (2020). Business Intelligence Capabilities And Firm Performance: A Study In China. International Journal Of Information Management, 2-15. Doi:Https://Doi.Org/10.1016/J.Ijinfomgt.2020.102232

Gupta, A. K., \& Gupta, N. (2020). Effect Of Corporate Environmental Sustainability On Dimensions Of Firm Performance E Towards Sustainable Development: Evidence From India. Journal Of Cleaner Production, 253, 1-14.

Pratono, A. H. (2016). Strategic Orientation And Information Technological Turbulence Contingency Perspective In Smes. Business Process Management, 22, 368-382. Doi:DOI 10.1108/BPMJ-05-2015-0066

Yasmin, M., Tatoglu, E., Kilic, H. S., Zaim, S., \& Delen, D. (2020). Big Data Analytics Capabilities And Firm Performance: An Integrated MCDM Approach. Journal Of Business Research, 114, 1-15.

Pratono, A.H. (2018), "Network Structure And Open Innovation: The Role Of Trust In Product Development”, International Journal Of Business Innovation And Research, Vol. 15 No. 1, Pp. 44-60.

Pratono, A.H. (2018), "From Social Network To Firm Performance: The Mediating Effect Of Trust, Selling Capability, And Pricing Capability”, Management Research Review, Vol. 41 No. 6, Pp. 680-700.

Jiang, W., Chai, H., Shao, J. And Feng, T. (2018), "Green Entrepreneurial Orientation For Enhancing Firm Performance: A Dynamic Capability Perspective”, Journal Of Cleaner Production, Vol. 198, Pp. 1311-1323.

Covin, J.G. And Miller, D. (2014), "International Entrepreneurial Orientation: Conceptual Considerations, Research Themes, Measurement Issues, And Future Research Directions", Entrepreneurship Theory And Practice, Vol. 38 No. 1, Pp. 11-44.

Mintzberg, H. And Waters, J. (1985), "Of Strategies, Deliberate And Emergent", Strategic Management Journal, Vol. 6 No. 3, Pp. 257-272.

Wiesner, R. And Millet, B. (2012), "Strategic Approaches In Australian Smes: Deliberate Or Emergent?”, Journal Of Management And Organization, Vol. 18 No. 1, Pp. 98122. 